\title{
Reproductive biology of the swamp racer Mastigodryas bifossatus (Serpentes: Colubridae) in subtropical Brazil
}

\author{
Pedro T. Leite ${ }^{1}$; Simone de F. Nunes ${ }^{1}$; Igor L. Kaefer ${ }^{1,2} \&$ Sonia Z. Cechin ${ }^{1}$ \\ ${ }^{1}$ Laboratório de Herpetologia, Departamento de Biologia, Universidade Federal de Santa Maria. Faixa de Camobi, Km 9, \\ 97105-900 Santa Maria, Rio Grande do Sul, Brasil.E-mail: pedroterraleite@hotmail.com; simonen@upf.br; \\ igorkaefer@hotmail.com; cechinsz@ccne.ufsm.br \\ ${ }^{2}$ Corresponding author.
}

\begin{abstract}
The swamp racer Mastigodryas bifossatus (Raddi, 1820) is a large snake of Colubrinae. It is widely distributed in open areas throughout South America. Dissection of 224 specimens of this species housed in herpetological collections of the southern Brazilian states of Rio Grande do Sul, Santa Catarina and Paraná provided information on its sexual dimorphism, reproductive cycle and fecundity in subtropical Brazil. Adult specimens of $M$. bifossatus average approximately $1190 \mathrm{~mm}$ in snout-vent length and females are larger than males. The reproductive cycle of females is seasonal, with secondary vitellogenesis occurring from July to December. However, examination of male gonads did not reveal signs of reproductive seasonality in this sex. Egg laying was recorded from November to January. The estimated recruitment period extends from February to April. The mean number of individuals per clutch is 15, and there is a positive correlation between female length and clutch size.
\end{abstract}

KEY WORDS. Fecundity; neotropics; reproduction; reproductive cycle; sexual dimorphism.

Mastigodryas Amaral, 1935 belongs to Colubrinae and contains large-sized, generally robust species, active during the day, and can display aggressive behavior (Cei 1993). The genus contains 11 species distributed from Mexico to southern Brazil, Bolivia, Paraguay and northern Argentina (Peters \& OrejasMiranda 1970, Lema 1994, Giraudo 2001).

Mastigodryas bifossatus (Raddi, 1820) occurs from Venezuela and Colombia to northern Argentina (Peters \& Orejas-Miranda 1970). Along its wide distribution range throughout the Neotropical region, five subspecies were recognized but subsequently invalidated, and are currently considered morphotypes (see Outeiral \& Lema 2003). In Brazil, M. bifossatus occurs predominantly in open areas of the Cerrado, Pantanal and Pampa biomes, and also occurs, in lower abundance, in the Amazonian and Atlantic forests (STRÜSSMANN \& SAZIMA 1993, Lema 2002, ArgÔlo 2004, Marques et al. 2004, Marques \& Muriel 2007).

The good representation of $M$. bifossatus in Brazilian herpetological collections has allowed studies on its ecology. Aspects of the natural history of M. bifossatus in southeastern South America were characterized by Marques \& Muriel (2007). Leite et al. (2007) provided information on its diet and habitat use in southern Brazil. Previous reports consist of occasional observations on the period of activity and spawning and food preferences, with no characterization of its reproductive cycle (Amaral 1978, Strüssmann \& Sazima 1993, Marques et al. 2004). In this study we present information on sexual dimorphism, maturity, reproductive season, spawning period, recruitment and fecundity of $M$. bifossatus (morphotype $M$. b. bifossatus) from subtropical domains of Brazil.

\section{MATERIAL AND METHODS}

\section{Study area}

Most of the subtropical region in Brazil corresponds to the states of Paraná, Santa Catarina and Rio Grande do Sul. The seasons are well defined, and precipitation is more or less evenly distributed throughout the year (Koeppen 1948). The vegetation includes several physiognomies such as savannas, steppes, dense and mixed rainy forests, and seasonal deciduous and semideciduous forests, which are distributed basically according to altitude and latitude (LerTe 2002), and also influenced by temperature and precipitation patterns (RODERJAN et al. 2002). In the southern Brazilian highlands, mixed rainforest is prevalent, where Araucaria angustifolia (Bertol.) Kuntze is the predominant species (Roderjan et al. 2002). Dense rainforest remnants of the Atlantic Forest predominates in the Serra do Mar range along the three states (RoderJan et al. 2002). The southern portion of Rio Grande do Sul state includes part of the Pampa biome (MARChIORI 2002, WAEChTER 2002), whereas in northern and northeastern Paraná, small portions of Cerrado (savanna) occur (Roderjan et al. 2002).

\section{Methods}

Data were obtained by dissection of 224 specimens of $M$. bifossatus preserved in the herpetological collections of the 
Universidade Federal de Santa Maria (ZUFSM, n = 108); the Museu de Ciências e Tecnologia of the Pontifícia Universidade Católica do Rio Grande do Sul, Porto Alegre (MCP, $\mathrm{n}=48$ ); the Instituto Butantan, São Paulo (IB, $\mathrm{n}=34$ ); the Museu de História Natural do Capão da Imbuia, Curitiba (MHCNI, n = 19) and the Museu de Ciências Naturais of the Fundação Zoobotânica do Rio Grande do Sul, Porto Alegre $(\mathrm{MCN}, \mathrm{n}=15)$. For each specimen we recorded the snout-vent length (SVL, in $\mathrm{mm}$ ), tail length (TL, in $\mathrm{mm}$ ), head length ( $\mathrm{HL}$, in $\mathrm{mm}$ ), sex (gonad analysis), number and length (in $\mathrm{mm}$ ) of vitellogenic follicles or oviductal eggs, length and width (both in $\mathrm{mm}$ ) of testicles, and the state of the deferent ducts.

The index of sexual size dimorphism (ISD) was calculated as follows: (mean SVL of the larger sex)/(mean SVL of the smaller sex) -1 . This index is expressed as positive if females are the larger sex and negative if males are the larger (Gibвons $\&$ Lovich 1990). For analyses of sexual dimorphism in SVL and relative tail length we did not consider individuals where the SVL could not be measured or those that presented tail loss, respectively. Only mature individuals were included in analyses of sexual dimorphism and all specimens were included in analyses of incidence of tail damage.

Follicles were measured to the nearest $0.01 \mathrm{~mm}$ with a digital caliper. Males were considered mature by the presence of convolute or opaque deferent ducts (SHINE 1988). Testicular volume (TV) was calculated by the ellipsoid formula (TV $=4 / 3 \pi a b^{2}$, where $\mathrm{a}=$ largest diameter, $\mathrm{b}=$ smallest diameter). Females were considered mature by the presence of follicles in secondary vitellogenesis (>13 mm) or of oviductal eggs. This is a different threshold size from that commonly used for other species (10 $\mathrm{mm}$, SHINE 1977), and was determined through visual examination of the seasonal distribution of follicle diameter. Moreover, the estimated age of sexual maturity was based on the analysis of the seasonal distribution of body-size classes (SHINE 1978).

The reproductive season was defined as the period from secondary vitellogenesis to the egg laying. Data on newborns came from captive laying. Captive females were taken from the field and maintained individually at natural temperature in sand-filled glass terraria $(100 \times 40 \times 40 \mathrm{~cm})$, with water supply, and were fed on mice. Fecundity was estimated by the number of follicles in secondary vitellogenesis, oviductal eggs and number of eggs per clutch.

Because testicular size is related to body length, we used analysis of covariance (ANCOVA) using SVL as covariate to test relative testicular volume among the seasons of the year. We log-transformed data from which variance were not homogeneous. We also compared TL of males and females with ANCOVA using SVL as covariate. Similar procedure was used to compare HL of males and females using trunk length (= SVL-HL) as the covariate. Sexual dimorphism in SVL and difference between the mean number of follicles in secondary vitellogenesis and the mean number of oviductal or laid eggs were evaluated through Mann-Whitney's U test. The re- lation between clutch size and female SVL was evaluated through Pearson's correlation test. All statistical analyses were performed using the program Statistica, version 5.0. For all analyses, significant results were considered when $\mathrm{p}<0.05$ (ZAR 1999).

\section{Specimens examined}

Universidade Federal de Santa Maria - ZUFSM: 2421, 2416, 2355, 2263, 211, 208, 121, 2334, 851, 872, 881, 1032, $983,1054,2403,2404,1190,1145,1153,1147,1207,1221$, 1050, 1084, 955, 1093, 817, 1334, 1087, 1352, 1141, 1991, 1172, 1173, 1248, 1204, 1307, 1311, 2461, 1314, 2073, 1342, 1106, 1967, 1211, 2454, 1345, 2399, 1391, 2002, 259, 2025, 248, 2049, $1031,2317,1006,1104,133,1290,1149,1255,398,1343,2413$, 1350, 2314, 1375, 2231, 264, 2191, 32, 1433, 67, 1446, 144, 1492, 500, 1450, 532, 1397, 1537, 1710, 1681, 1764, 2418, 1790, $1708,1775,1785,1876,1393,1845,1804,1934,1829,1950$, 1939, 1612, 2644, 1654, 2643, 269, 2629, 127, 2485. Fundação Zoobotânica do Rio Grande do Sul, Porto Alegre - MCN: 86, 91, 88, 74, 2736, 7053, 90, 84, 83, 77, 93, 760, 78, 794, 73, 6044. Pontifícia Universidade Católica do Rio Grande do Sul, Porto Alegre - MCP: 14623, 14665, 14149, 12603, 14685, 14137, 14681, 11715, 11174, 5851, 6356, 6205, 12808, 14122, 6650, 11373, 5685, 5848, 11906, 11733, 13214, 11905, 9452, 11173, 5856, 5847, 5852, 6358, 12051, 13417, 11402, 11108, 12634, 12507, 12635, 5853, 5864, 5849, 5724, 5855, 14828, 14669, 14664, 14652, 14622, 14651, 12812, 13213. Instituto Butantan, São Paulo - IB: 23389, 23401, 27290, 30342, 11464, 57361, 22185, 24282, 23809, 30506, 44732, 44724, 44700, 44736, 44722, 27922, 22576, 26903, 23388, 27614, 23050, 27289, 15976, 11609, 32239, 27613, 31572, 19549, 24283, 49903, 19466, 23217, 22270, 44713 Museu de História Natural do Capão da Imbuia, Curitiba - MHNCI: 2644, 640, 9436, 1288, 952, 570, 4187, 641, 6127, 4304, 6545, 2427, 4245, 4302, 642, $2643,8222,932,3678$.

\section{RESULTS}

\section{Sexual dimorphism}

SVL of newborns ranged from 270 to $315 \mathrm{~mm}$ (mean = 287, $\mathrm{sd}=16, \mathrm{n}=7$ ) and TL from 97 to $117 \mathrm{~mm}($ mean $=106$, $\mathrm{sd}=7.5, \mathrm{n}=7$ ). Mature male SVL ranged from 830 to $1480 \mathrm{~mm}$ (mean $=1113$, sd $=145, \mathrm{n}=101)$, and TL from 295 to $520 \mathrm{~mm}$ (mean $=408, \mathrm{sd}=46, \mathrm{n}=81)$. Mature female SVL ranged from 930 to $1560 \mathrm{~mm}($ mean $=1190, \mathrm{sd}=139, \mathrm{n}=87)$ and TL from 295 to $484 \mathrm{~mm}$ (mean $=395, \mathrm{sd}=39, \mathrm{n}=63)$. Mature females are larger in size than mature males (Mann-Whitney, $\mathrm{U}=$ 3193.5, $\mathrm{Z}=3.2, \mathrm{p}=0.001$ ), and the degree of sexual size dimorphism in body size is 0.07 . Adult males and females did not differ in head length (ANCOVA, $\mathrm{F}=0.02, \mathrm{p}=0.87, \mathrm{n}=177$ ). However, adult males had a larger relative TL (ANCOVA, $\mathrm{F}=54.55, \mathrm{p}<0.0001, \mathrm{n}=157$ ) than females (Fig. 1). Among the analyzed specimens $22.76 \%(\mathrm{n}=51)$ had damaged tails ( $20 \%$ in males, $\mathrm{n}=20$, and $27 \%$ in females, $\mathrm{n}=31$ ). 


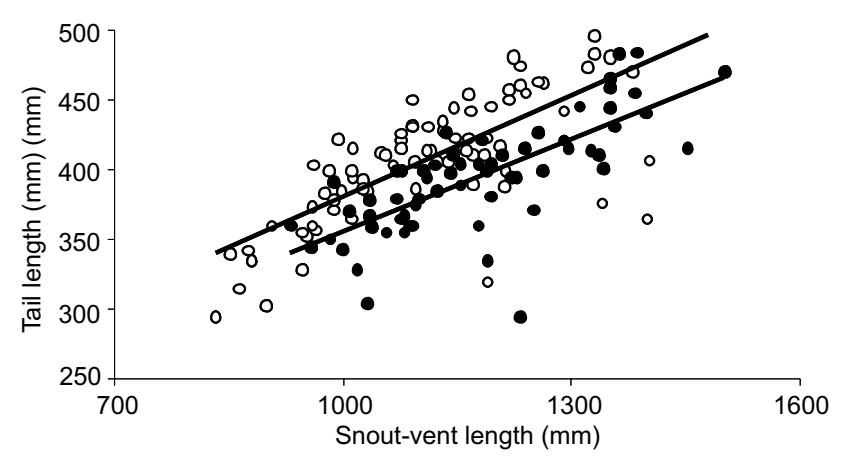

Figure 1. Relationship between snout-vent length (SVL) and tail length $(\mathrm{TL})$ in male $(\bigcirc)$ and female $(\bullet)$ Mastigodryas bifossatus in subtropical Brazil.

\section{Sexual maturity}

The smallest mature male was $830 \mathrm{~mm}$ in SVL. The SVL of the smallest mature female was $930 \mathrm{~mm}$. The seasonal distribution of the snout-vent length of $M$. bifossatus indicated that the body size of individuals almost doubles during the first year, and males and females attain sexual maturity between the ages of 18 and 24 months respectively (Figs 2 and 3).
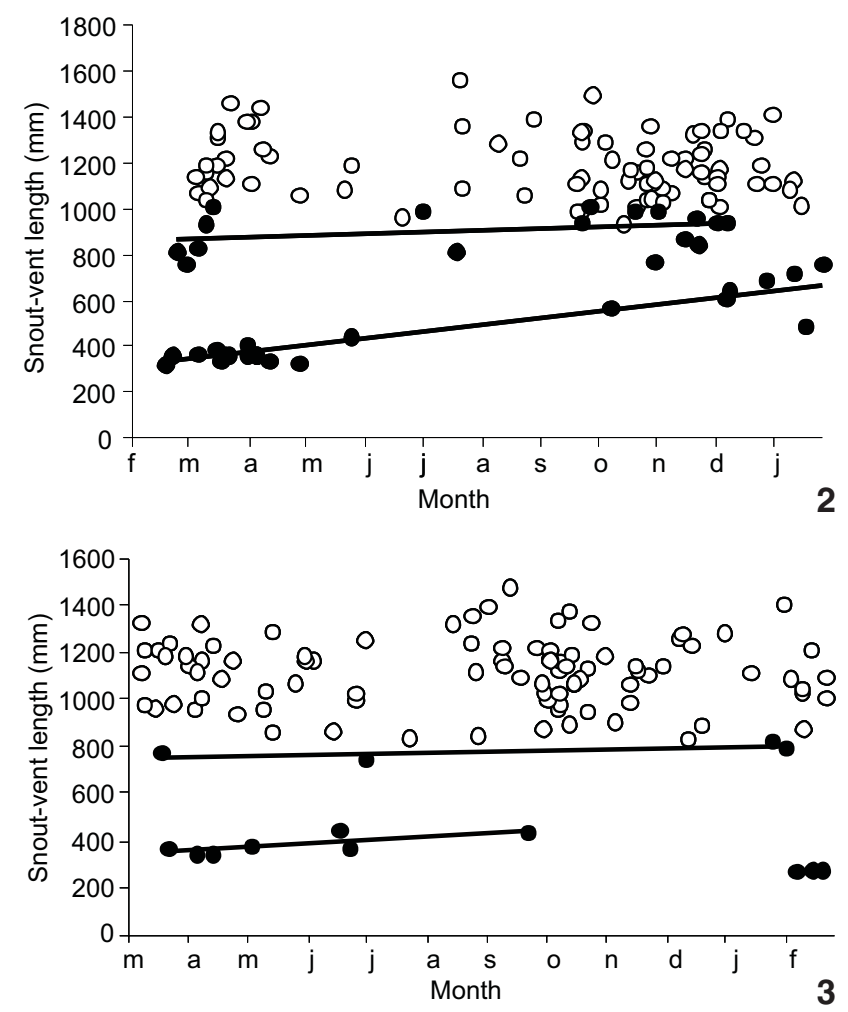

Figures 2-3. Seasonal distribution of body size in (2) female and (3) male of Mastigodryas bifossatus in subtropical Brazil. ( $\bigcirc)$ mature, (๑) immature. Regression lines show inferred growth pattern.

\section{Reproductive season, spawning period and birth of the nestlings}

Mastigodryas bifossatus shows secondary vitellogenesis from July to December, while oviductal eggs from October to December (Fig. 4), indicating a seasonal reproductive cycle for females. Egg-laying was recorded from November to January $(\mathrm{n}=3)$ in captivity. A female collected on May $2^{\text {nd }}, 2004$ and kept in captivity laid 14 eggs on January 13, 2005, of which only 3 eggs completed their development. The mean SVL, TL and weight of the newborns were, respectively, $305 \mathrm{~mm}$ (range $=295-315 \mathrm{~mm}, \mathrm{sd}=10), 104.6 \mathrm{~mm}($ range $=102-109, \mathrm{sd}=3.78)$ and $8.6 \mathrm{~g}$ (range $=7.5-9.7 \mathrm{~g}$, sd $=1.1)$. A female collected on November 9, 1997 laid 22 eggs, of which four newborn erupted in February 1998. The mean SVL and TL of the newborns were, respectively, $274.25 \mathrm{~mm}($ range $=270-278 \mathrm{~mm}$, $\mathrm{sd}=3.3 ; \mathrm{n}=4)$ and $107 \mathrm{~mm}$ (range $=97-117, \mathrm{sd}=9.9 ; \mathrm{n}=4$ ). Another female collected on November 10, 2005 laid 10 eggs on January 09, 2006, but no nestlings erupted from the clutch.

Five females had, concomitantly, oviductal eggs and follicles in secondary vitellogenesis. One female analyzed immediately after laying also had vitellogenic follicles.

There was no difference in relative testicular volume among seasons (ANCOVA, $\mathrm{F}=2.10, \mathrm{p}=0.10, \mathrm{n}=84$ ).

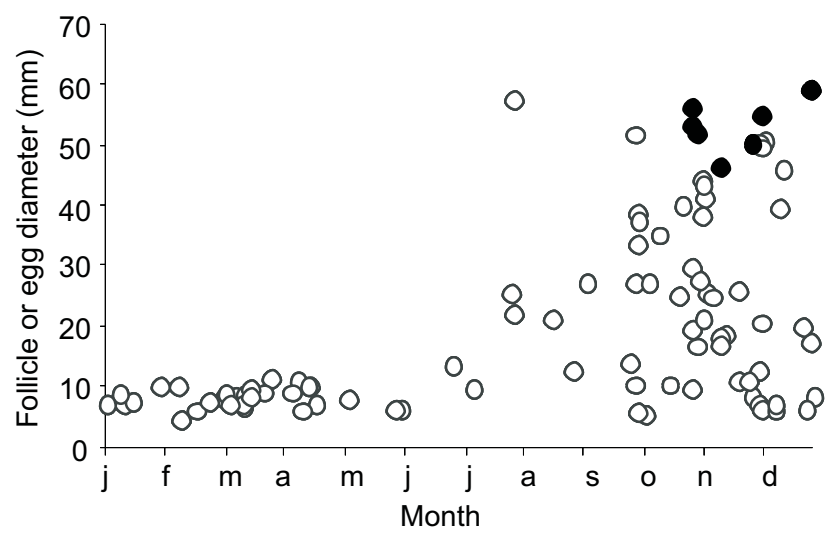

Figure 4. Seasonal variation in the diameter of the largest follicle $(\bigcirc)$ or oviductal eggs ( $)$ in Mastigodryas bifossatus in subtropical Brazil.

\section{Fecundity}

The number of vitellogenic follicles in M. bifossatus ranged from 3 to 31 (mean $=14.11$, sd $=7.84, \mathrm{n}=36$ ), the number of oviductal eggs ranged from 8 to 22 (mean $=13$, $\mathrm{sd}=5.5, \mathrm{n}=7)$ and the number of eggs per clutch ranged from 10 to 22 (mean $=15$, sd =6, n = 3). There was no significant difference between the mean number of follicles in secondary vitellogenesis and the mean number of oviductal or laid eggs (Mann-Whitney, $\mathrm{U}=123, \mathrm{Z}=0.209, \mathrm{p}>0.05, \mathrm{n}=44$ ). Clutch size and female SVL showed a significant positive correlation (Pearson, $\mathrm{r}=0.34, \mathrm{p}<0.05, \mathrm{n}=45$ ) (Fig. 5). 


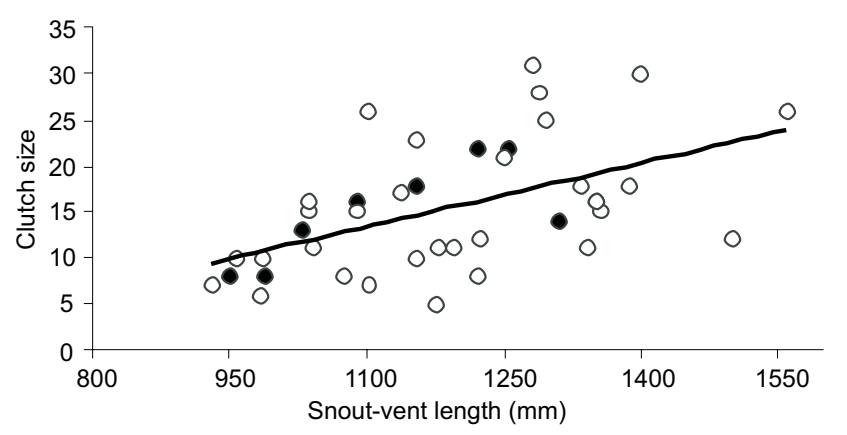

Figure 5. Relationship between snout-vent length (SVL) and clutch size in female Mastigodryas bifossatus in subtropical Brazil. ( () vitellogenic follicles, ( ) oviductal or laid eggs.

\section{DISCUSSION}

\section{Sexual dimorphism}

Differences in body size between males and females are considered evolutionary adaptations that increase reproductive success in snakes (SHINE 1978). These differences can be interpreted to other observed patterns such as male-male combat, the relationship between female body size and clutch, reproductive frequency and geographic distribution of individuals (SHINe 1978, 1994a). In most cases, female colubrids attain larger SVL than conspecific males (FIтсH 1981). The small difference in size between males and females of M. bifossatus (ISD $=0.07$ ) can be related to increased fecundity in females (SHINE 1993, 1994a).

Male-male ritual combats in $M$. bifossatus have not been reported, and there are no known cases in the genus. In Colubridae, this behavior is reported mainly for Colubrinae (SHINE 1994a), for instance Chironius carinatus (Linnaeus, 1758) (STARACE 1998) in the Amazon and Chironius bicarinatus (Wied, 1820) (Almeida-Santos \& Marques 2002) in southeastern Brazil. Considering that the presence of this behavior influences the degree of sexual dimorphism (SHine 1978, 1994a), we cannot discard the hypothesis that M. bifossatus has male-male combat, because colubrids with a similar degree of sexual dimorphism, such as the colubrine Masticophis lateralis (Hallowell, 1853), show this type of behavior (see SHINe 1994a). Moreover, analyses of specimens of $M$. bifossatus from southeastern Brazil indicated equivalent body sizes for males and females (MARQUES \& Muriel 2007). However, we highlight that field behavioral observations are needed to evaluate the existence of male-male combat in this species.

The lack of sexual dimorphism in head size of snakes was related to intersexual diet similarities (SHINE \& CReW 1988). This hypothesis was corroborated by LeiTe et al. (2007), who did not observe any difference in prey size ingested by male and female M. bifossatus in subtropical Brazil.

Males of M. bifossatus have a proportionally larger relative tail length than females. This pattern is very common in snakes (SHINE 1993), and is due mainly to the hemipenial accommodation (KING 1989). Tail length also influences male reproductive success, acting as a sexual selection factor (SHINE et al. 1999). Mastigodryas bifossatus has a quite long tail for a species with preferentially terrestrial habits. In this species, this character can be related to the capacity for autotomy, a poorly known tactic employed as a defensive mechanism by both sexes (Arnold 1988, Prudente et al. 2007).

The data obtained in this study confirm the high incidence of tail breakage in M. bifossatus (22.76\%), as previously recorded for specimens from various localities in Brazil (46.7\%, Ferreira \& OUteiral 1998). Other colubrids, such as Coniophanes fissidens (Günther, 1858) and Dendrophidion dendrophis (Schlegel, 1837), also show this type of damage (Zug et al. 1979, Prudente et al. 2007). Tail breakage can act as an anti-predator and escape mechanism (Zug et al. 1979, Prudente et al. 2007), and is used by many lizard and some snake species (ARNOLD 1988). According to White et al. (1982), the incidence of this type of damage increases in larger individuals.

\section{Sexual maturity}

Differences in growth rates among species or even within a species are related to the climate conditions of each geographical locality, especially the length of the growing season (LuIselLI et al. 1997). The same may occur with M. bifossatus, because individuals that were born at the beginning of the recruitment period (February) enjoy a longer growth period before winter than those that hatch at its end (May). This allows males of small-sized species such as Atractus reticulatus (Boulenger, 1885) and Lystrophis dorbignyi (Duméril, Bibron \& Duméril, 1854) attain sexual maturity at smaller sizes than females, soon in their first reproductive season (Shine 1980, Marques \& Puorto 1998, Balestrin \& Di-Bernardo 2005). However, in spite of the duplication of the body size in male M. bifossatus in the first year of life (MARques \& Muriel 2007, this study), sexual maturity is probably reached only in the second reproductive season. In females, the age of sexual maturity may be delayed in relation to conspecific males, because of the high energetic costs of reproduction (SHINe 1978). Females must reach larger body sizes in order to produce larger egg masses and, consequently, more nestlings (Luiselli et al. 1996).

\section{Reproductive season, laying period and birth of the nestlings}

Females of M. bifossatus showed reproductive seasonality, with secondary vitellogenesis lasting approximately five months in southern Brazil. A similar pattern was previously observed for several snake species in subtropical regions (Duellman 1978, Vitt 1983, Vitt \& Vangilder 1983). Nevertheless, in the lower latitudes of southeastern South America, Marques \& Muriel (2007) classified the reproductive cycle of $M$. bifossatus as continuous, with ovarian follicles in vitellogenesis found virtually during all months of the year. Additionally, these authors indicated pronounced reproductive season- 
ality for this species, with recruitment peaking at the end of the rainy season. Our results suggest that $M$. bifossatus shows a more-pronounced reproductive seasonality in the subtropical region, with absence of vitellogenesis during the coldest months and an estimated recruitment period that extends from February to April.

Phylogenetic factors play an important role in determining reproductive seasonality in snakes (SEIGEL \& FoRD 1987). However, the seasonal pattern is probably imposed by the pronounced temperature variations in the region studied, which restricts the occurrence of reproduction to the warmest months of the year (Pontes \& Di-Bernardo 1988, Di-Bernardo et al. 2007), as in snakes in temperate climates (Kofron 1983). Studies in southeastern Brazil have also indicated reproductive seasonality in species of Colubrinae, such as C. bicarinatus (MARQUes \& SAZIMA 2004), Spilotes pullatus (Linnaeus, 1758) (MARques \& SAZIMA 2004, HaUzMan et al. 2005) and Tantilla melanocephala (Linnaeus, 1758) (Marques \& Puorto 1998).

Factors such as temperature and reproductive condition in females can influence testicular development in male snakes (AldRIDGe 1975, Bull et al. 1997). In M. bifossatus, the testicular relative volume did not show significant changes during the year. This indicates an absence of reproductive seasonality, because the increase in testicular volume is positively related to the degree of sexual hormone expression (Merilä \& SHeLdon 1999). One of the factors responsible for reproductive non-seasonality in subtropical male snakes seems to be the absence of a pronounced dry season (SAINT-GIRons 1982). In addition to this factor, we believe that the reproductive asynchrony between male and female M. bifossatus reflects the lower energetic cost for production of the male gametes (see Olsson et al. 1997 for discussion).

\section{Fecundity}

The available data indicate that M. bifossatus can produce from 8 to 18 eggs (Amaral 1978, Leitão De Araújo 1978). However, in this study we found specimens containing up to 22 eggs. The mean number of 15 eggs found for the species in the present study is relatively low considering the large body size of this species, but it is similar to that found for the same species in southeastern South America (see Marques \& Muriel 2007). Smaller-sized Neotropical colubrids, such as Philodryas patagoniensis (Girard, 1858) and the viviparous Tomodon dorsatus Duméril, Bibron \& Duméril, 1854, show fecundity similar to M. bifossatus (Fowler et al. 1998, BizerRa et al. 2005). This can be explained by the larger size of $M$. bifossatus newborns as compared to those of other Neotropical oviparous snakes (PONTES \& Di-BERnardo 1988).

The positive correlation between snake size and number of eggs in M. bifossatus reinforces a broadly documented intraand interspecific pattern (SEIGel \& Ford 1987, Shine 1994b) recorded in specimens of this species from lower latitudes in Brazil (Marques \& Muriel 2007) and in various Neotropical colubrid species, such as Philodryas olfersii (Lichtenstein, 1823), P. nattereri (Steindachner, 1870) (VITT 1980), Sibon sanniola (Cope, 1867) (Kofron 1983) and T. melanocephala (Marques \& Puorto 1998).

As suggested in a study on M. bifossatus in southeastern South America (Marques \& Muriel 2007), we believe that it is capable of multiple egg layings. This hypothesis is based on the large number of follicles in secondary vitellogenesis and the simultaneous presence of oviductal eggs in some females, although the conversion of follicles in eggs in the same reproductive season is not guaranteed (SEIGEL \& Ford 1987). Multiple egg layings were recorded in Tropidonophis mairii (Gray, 1841) in nature (BROWN \& SHINE 2002). There are records of multiple egg layings in Micrurus corallinus (Merrem, 1820) and Simophis rhinostoma (Schlegel, 1837) in captivity (MARQues 1996, Jordão \& Bizerra 1996), although these data can distort reproductive patterns in snakes, mainly because of the increased food availability in captivity (SEIGEL \& Ford 1987).

\section{ACKNOWLEDGEMENTS}

We thank Marcos Di-Bernardo (in memoriam), Márcio B. Martins, Ana L. Prudente and two anonymous reviewers for helpful comments that improved this manuscript. We also thank Rafael Balestrin for valuable suggestions during the study, and Anaide Aued for assistance in laboratory work. Daiani Kochhann helped in statistical analyses. PTL thanks CAPES for a Master's student fellowship.

\section{LITERATURE CITED}

ALDRIDGE, R.D. 1975. Environmental control of spermatogenesis in the rattlesnake, Crotalus viridis. Copeia 1975 (3): 493-496.

Almeida-Santos, S.M. \& O.A.V. Marques. 2002. Male-male ritual combat in the colubrid snake Chironius bicarinatus from the Atlantic Forest, southeastern Brazil. Amphibia-Reptilia 23: 528-533.

Amaral, A. 1978. Serpentes do Brasil: iconografia colorida. São Paulo, Editora da Universidade de São Paulo, Melhoramentos, 248p.

Argôlo, A.J.S. 2004. Serpentes dos cacauais do sudeste da Bahia. Ilhéus, Editus, 260p.

Arnold, E.N. 1988. Caudal autotomy as a defense, p. 235-273. In: C.Gans \& R.B. Huey (Eds). Biology of the Reptilia, Ecology B: defense and life history. New York, Alan R. Liss, vol.16, 659p.

Balestrin, R.F. \& M. Di-Bernardo. 2005. Reproductive biology of Atractus reticulatus (Boulenger, 1885) (Serpentes, Colubridae) in Southern Brazil. Herpetological Journal 15: 195-199.

Bizerra, A.; O.A.V. Marques \& I. Sazima. 2005. Reproduction and feeding of the colubrid snake Tomodon dorsatus from southeastern Brazil. Amphibia-Reptilia 26: 33-38.

BRown, G.P. \& R. SHINE. 2002. Reproductive ecology of a tropical natricine snake, Tropidonophis mairii (Colubridae). Journal of Zoology 258: 63-72. 
Bull, K.H.; R.T. MAson \& J. WhitTiER. 1997. Seasonal testicular development and sperm storage in tropical and subtropical populations of the Brown Tree Snake (Boiga irregularis). Australian Journal of Zoology 45: 479-488.

Cei, J.M. 1993. Reptiles del noroeste, nordeste y este de la Argentina: Herpetofauna de las selvas subtropicales, Puna y Pampas. Torino, Museu Regionale di Scienze Naturali, Monografia XIV, 949p.

Di-Bernardo, M.; M. Borges-Martins; R.B. de Oliveira \& G.M.F. Pontes. 2007. Taxocenoses de serpentes de regiões temperadas do Brasil, p. 222-263. In: L.B. NASCimento \& M.E. Oliveira (Eds). Herpetologia no Brasil II. Belo Horizonte, Sociedade Brasileira de Herpetologia, 354p.

Duellman, W.E. 1978. The biology of an equatorial herpetofauna in Amazonian Ecuador. University of Kansas Museum of Natural History Miscellaneous Publications 65: 1-352.

Ferreira, V.L. \& A.O. Outeiral. 1998. Mastigodryas bifossatus (Raddi, 1820): Tail breakage (Serpentes). Herpetological Review 29 (1): 141-141.

FIтсH, H.S. 1981. Sexual size differences in reptiles. University of Kansas Museum of Natural History Miscellaneous Publications 70: 1-72.

Fowler, I.R.; M.G. SALOMÃo \& R.S. JoRdão. 1998. A description of the female reproductive cycle in four species from the neotropical colubrid snake Philodryas (Colubridae, Xenodontinae). The Snake 28: 71-78.

Gibbons J.W. \& J.E. Lovich. 1990. Sexual dimorphism in turtles with emphasis on the slider turtle (Trachemys scripta). Herpetological Monographs 4: 1-29.

Giraudo, R.A. 2001. Serpientes de la selva Paranaense y del Chaco Humedo. L.O.L.A., Buenos Aires, 325p.

Hauzman, E.; A.C.O.R. Costa \& R.R. Scartozzoni. 2005. Spilotes pullatus: Reproduction. Herpetological Review 36 (3): 328.

JoRDÃo, R.S. \& A.F. BizerRA. 1996. Reprodução, dimorfismo e atividade de Simophis rhinostoma (Serpentes, Colubridae). Revista Brasileira de Biologia 56: 507-512.

KING, R.B. 1989. Sexual dimorphism in snake tail length: sexual selection, natural selection, or morphological constraint? Biological Journal of the Linnean Society 38: 133-154.

Koeppen, W. 1948. Climatologia. Mexico, Fundo de Cultura Economica, 478p.

Kofron, C.P. 1983. Female reproductive cycle of the neotropical snail-eating snake Sibon sanniola in northern Yucatan, Mexico. Copeia 1983 (4): 963-969.

Leitão-De-Araújo, M. 1978. Notas sobre ovos de serpentes (Boidae, Colubridae, Elapidae e Viperidae). Iheringia, Série Zoologia, 51: 9-37.

LeITe, P.F. 2002. Contribuição ao conhecimento fitoecológico do sul do Brasil. Ciência \& Ambiente 24: 51-63.

Leite, P.T.; S.F. Nunes \& S.Z. Cechin. 2007. Dieta e uso de habitat da jararaca-do-brejo, Mastigodryas bifossatus Raddi (Serpentes, Colubridae) em domínio subtropical do Brasil. Revista Brasileira de Zoologia 24 (3): 729-734.
Lema, T. 1994. Lista comentada dos répteis ocorrentes no Rio Grande do Sul, Brasil. Comunicações do Museu de Ciências e Tecnologia da PUCRS, Série Zoologia, 7: 41-150.

Lema, T. 2002. Os répteis do Rio Grande do Sul. Atuais e fósseis - biogeografia - ofidismo. Porto Alegre, EDIPUCRS, $166 \mathrm{p}$.

Luiselli, L.; M. Capula \& R. Shine. 1996. Reproductive output, costs of reproduction, and ecology of the smooth snake, Coronella austriaca, in the eastern Italian Alps. Oecologia 106: $100-110$.

Luiselli, L.; M. Capula \& R. Shine. 1997. Food habits, growth rates, and reproductive biology of the grass snakes, Natrix natrix (Colubridae) in the Italian Alps. Journal of Zoology 241: 371-380.

Marchiori, J.N.C. 2002. Considerações terminológicas sobre os campos sulinos. Ciência \& Ambiente 24: 139-150.

Marques, O.A.V. 1996. Reproduction, seasonal activity and growth of the coral snake, Micrurus corallinus (Elapidae), in the southeastern Atlantic forest in Brazil. Amphibia-Reptilia 17: 277-285.

Marques, O.A.V.; A. Eterovic \& I. Sazima. 2004. Snakes of the Brazilian Atlantic Forest: an illustrated field guide for the Serra do Mar range. Ribeirão Preto, Holos Editora, 205p.

Marques, O.A.V. \& A.P. Muriel. 2007. Reproductive biology and food habits of the swamp racer Mastigodryas bifossatus from southeastern South America. Herpetological Journal 17: 104-109.

Marques, O.A.V. \& G. Puorto. 1998. Feeding, reproduction and growth in the crowned snake Tantilla melanocephala (Colubridae), from southeastern Brazil. Amphibia-Reptilia 19: 311-318.

Marques, O.A.V. \& I. Sazima. 2004. História natural dos répteis da Estação Ecológica Juréia-Itatins, p. 254-274. In: O.A.V. MARQues \& W. Duleba (Eds). Estação Ecológica Juréia-Itatins: ambiente físico, flora e fauna. Ribeirão Preto, Holos Editora, $384 \mathrm{p}$.

Merilä, J. \& B.C. Sheldon. 1999. Testis size variation in the greenfinch Carduelis chloris: relevance for some recent models of sexual selection. Behavioral Ecology and Sociobiology 45: 115-23.

Olsson, M.; T. MADSEN \& R. Shine. 1997. Is sperm really so cheap? Costs of reproduction in male adders, Vipera berus. Proceedings of the Royal Society Series B 264: 455-459.

Outeiral, A.B. \& T. Lema. 2003. Estudo morfológico comparativo hemipeniano das subespécies de Mastigodryas bifossatus (Raddi, 1820) (Serpentes: Caenophidia: Colubridae: Colubrinae). Acta Biologica Leopoldensia 25 (1): 113-122.

Peters, J.A. \& B. Orejas-Miranda. 1970. Catalogue of the Neotropical Squamata. Part I. Snakes. Bulletin of the United States National Museum 297: 1-347.

Pontes, G.M. \& M. Di-Bernardo. 1988. Registros sobre aspectos reprodutivos de serpentes ovíparas neotropicais (Serpentes, Colubridae e Elapidae). Comunicações do Museu de Ciên- 
cias e Tecnologia da PUCRS, Série Zoologia, 1: 123-149.

Prudente, A.L.; G.F. Maschio; C.E. Yamashina \& M.C. Santos-CosTA. 2007. Morphology, reproductive biology and diet of Dendrophidion dendrophis (Schlegel, 1837) (Serpentes, Colubridae) in Brazilian Amazon. South American Journal of Herpetology 2 (1): 53-58.

Roderjan, C.V.; F. Galvão; Y.S. KuniYoshi \& G.G. HatschbaCh. 2002. As unidades fitoecológicas do Estado do Paraná. Ciência \& Ambiente 24: 74-92.

SAint-Girons, H. 1982. Reproductive cycles of male snakes and their relationships with climate and female reproductive cycles. Herpetologica 38 (1): 5-16.

Seigel, R.A. \& N.B. Ford. 1987. Reproductive ecology, p. 210252. In: R. A. Seigel, J.T. Collins \& S.S. NovaK (Eds). Snakes, Ecology and Evolutionary Biology. New York, McMillan Publishing Company, XIV+529p.

SHINE, R. 1977. Reproduction in Australian elapid snakes. II. Female reproductive cycles. Australian Journal of Zoology 25: 655-666.

SHINE, R. 1978. Sexual size dimorphism and male combat in snakes, Oecologia 33: 269-278.

SHINE, R. 1980. Comparative ecology of three Australian snake species of the genus Cacophis (Serpentes: Elapidae). Copeia 1980 (4): 831-838.

SHINE, R. 1988. Food habits and reproductive biology of small Australian snakes of the genera Unechis and Suta (Elapidae). Journal of Herpetology 22 (3): 307-315.

SHINE, R. 1993. Sexual dimorphism in snakes, p. 49-86. In: R.A. Seigel; J.T. Coldins \& S.S. NovaK (Eds). Snakes: ecology \& behavior. New York, McGraw-Hill, XVI+414p.

SHINE, R. 1994a. Sexual size dimorphism in snakes revisited. Copeia 1994 (2): 326-246.

SHINE, R. 1994b. Allometric patterns in the ecology of Australian snakes. Copeia 1994 (4): 851-867.

Shine, R. \& D. Crew. 1988. Why male garter snake have small heads: the evolution and endocrine control of sexual dimorphism. Evolution 42: 1105-1110.

Shine, R.; M.M. Olsson; I.T. Moore; M.P. Lemaster \& R.T. Mason. 1999. Why do male snakes have longer tails than females? Proceedings of the Royal Society of London B 266: 21472151.

Starace, F. 1998. Guide des serpents et amphisbènes de Guyane Française. Guadeloupe, Ibis Rouge Editions, 449p.

Strüssmann, C. \& I. Sazima. 1993. The snake assemblage of the Pantanal at Poconé, western Brazil: faunal composition and ecological summary. Studies on Neotropical Fauna and Environment 28: 157-168.

VITT, L.J. 1980. Ecological observations on sympatric Philodryas (Colubridae) in the northeastern Brazil. Papéis Avulsos de Zoologia 34: 87-98.

VITT, L.J. 1983. Ecology of an anuran-eating guild of terrestrial tropical snake. Herpetologica 39: 52-66.

VitT, L.J. \& L.D. VANGILDER. 1983. Ecology of a snake community in northeastern Brazil. Amphibia-Reptilia 4: 273-296.

Waechter, J.L. 2002. Padrões geográficos na flora atual do Rio Grande do Sul. Ciência \& Ambiente 24: 93-108.

White, D.R.; J.C. Mitchell \& W.S. Woolcott. 1982. Reproductive cycle and embrionic development of Nerodia taxispilota (Serpentes: Colubridae) at the northeastern edge of its range. Copeia 1982 (3): 646-652.

ZAR, J.H. 1999. Biostatistical analysis. New Jersey, Prentice Hall, $662 p$.

Zug, G.R.; S.B. Hedges \& S. SunKel. 1979. Variation in reproductive parameters of three neotropical snakes, Coniophanes fissidens, Dipsas catesbyi and Imantodes cenchoa. Smithsonian Contributions to Zoology 300: 1-20.

Submitted: 14.VI.2008; Accepted: 13.XII.2008.

Editorial responsibility: Ana Lúcia da Costa Prudente 